\title{
BEAM CONSTRUCTION IMPACT ANALYSIS BASED ON LIFE CYCLE ASSESSMENT (LCA) USING NETWORK FLOW DIAGRAM
}

\author{
Bernardus Martino ${ }^{1}$, Yatnanta Padma Devia ${ }^{2}$, Indradi Wijatmiko \\ ${ }^{1,2,3}$ Department of Civil Engineering, Brawijaya University, Malang, East Java, Indonesia \\ Correspondence : martinobernardus@gmail.com; yatnanta@ub.ac.id ; indradi@ub.ac.id
}

\begin{abstract}
Global warming is a problem that impacts in many various sectors include construction. Emission of carbon dioxide $\left(\mathrm{CO}_{2}\right)$, one of causes of global warming, can be emitted from construction projects. The alternative method that able to calculate $\mathrm{CO}_{2}$ emissions is Life Cycle Assessment approach. The purpose of this study is to predict $\mathrm{CO}_{2}$ emission from all beam types using network flow diagram of Life Cycle Assessment in real estate project of $216 \mathrm{~m}^{2}$ type house. The analysis calculated by SimaPro 9.0 software. The results of this research indicated that from four types of beams used in real estate, beam-type 25/50 and beam-type 15/30 have the largest percentage of $\mathrm{CO}_{2}$ emission in $41.9 \%\left(4,610 \mathrm{~kg} \mathrm{CO}_{2}\right.$-eq) and $39.9 \%\left(4,380 \mathrm{~kg} \mathrm{CO}_{2}\right.$-eq) of the total $\mathrm{CO}_{2}$ emission of all beam types, respectively. A conventional method of beam construction resulted $\mathrm{CO}_{2}$-eq emission that come from rebar of $31.20 \%\left(3.426 \mathrm{~kg} \mathrm{CO}_{2}\right.$-eq) and cement $1.09 \%\left(120 \mathrm{~kg} \mathrm{CO}_{2}\right.$-eq). For the ready mix method, the largest $\mathrm{CO}_{2}$-eq emission are dominated by ready mix at $20.20 \%(2,200 \mathrm{~kg}$ $\mathrm{CO}_{2}$-eq) and wooden blocks $46.90 \%\left(5,150 \mathrm{~kg} \mathrm{CO}_{2}\right.$-eq).
\end{abstract}

Keywords : $\mathrm{CO}_{2}$ Emission, Life Cycle Assessment, Global Warming, SimaPro 9.0

\section{INTRODUCTION}

Construction projects are considered to have a major role in environmental changes on the surface of the earth. In one cycle construction project, started from the pre-construction stage to the operational stage, the exploitation of limited natural resources cannot be avoided. According to Ervianto et.al (2013), based on result of many research data, it is declared that more than $50 \%$ of all waste generated comes from construction activities [1]. The construction materials have significant sources of carbon dioxide $\left(\mathrm{CO}_{2}\right)$ emissions that derived from cement $(30.3 \%)$, ceramics $(20.3 \%)$ and steel $(18.7 \%)$.

Two of three elements namely cement and steel are the main materials in beam production [2]. Beam is a structural load buffer of a building that physically distributed in the horizontal direction. The beam manufactures use many types of materials. The natural exploitation, transportation, production, and construction of beam indicated generate the $\mathrm{CO}_{2}$ emission. Therefore, it requires an appropriate and fast analysis method in calculating its environmental impact.
Life Cycle Assessment (LCA) is one of method to find out how the goods or services of a product are identified from beginning to end, to find out the effect caused, and to analyze the percentage of the impact. LCA is a method used to assess the environmental impacts associated with a product or service. By using the LCA of beam in network flow diagram, the $\mathrm{CO}_{2}$ emission can be calculated and alternative solutions can be provided [3].

\section{LITERATURE REVIEW}

Beam is a horizontal trunk of a structural frame that bears a perpendicular load along the trunk that consisting of walls, plates, or roofs of buildings and channel them on a pedestal or structure underneath [4]. In the life cycle of beam, the carbon footprint will be generated. Carbon footprint is the amount of greenhouse gas emissions and removals in a product system expressed as the emission $\mathrm{CO}_{2}$ equation. The greenhouse gas ( $\mathrm{GHG}$ ) or the $\mathrm{CO}_{2}$-equation usually in Life Cycle Assessment calculated using a single impact category of climate change. Carbon footprint usually calculated in units of tons of carbon dioxide equivalent or 
$\mathrm{CO}_{2}$ [5]. The basic for calculated $\mathrm{GHG}$ emission or $\mathrm{CO}_{2}$ emissions is [6]:

GHG Emissions $=\sum \mathrm{A}_{\mathrm{i}} \times \mathrm{E}_{\mathrm{fi}}$

GHG Emissions $=$ Amount of $\mathrm{CO}_{2}$ emissions ( $\mathrm{kg} \mathrm{CO}_{2}$-eq)

$\Sigma \mathrm{Ai}=$ Consumption of type fuel (TJ)/

Production Capacity of

Industrial Activities

Efi $=$ Emission factor $(\mathrm{kg} / \mathrm{TJ})$

Life-Cycle Assessment (LCA) is a method used to evaluate the consumption of energy and raw materials, emissions released to the environment, and other waste related to the life cycle of a product or system. To determine the scope of the Life Cycle Assessment (LCA) there are several approach of Life Cycle Assessment:

1. Cradle to grave, where in this section the scope starts from the raw material to the product operation process.

2. Cradle to gate, where in this section the scope starts from the raw material to the gate before the operation process.

3. Gate to gate, where the scope is the shortest cycle than other cycles, because this scope only reviews the closest activities

4. Gate to grave, where the scope starts from the raw material to the recycling of the material [7].

SimaPro is one of software used to analyze Life Cycle Assessment with complete service facilities. Databases or commonly called libraries provided by SimaPro are a combination of clusters data from eco-invent, US Life Cycle Inventory Database (USLCI), The European Life Cycle Database (ELCD), agri-footprint, and many other databases. The results of the analysis of the software are divided into three categories namely emissions to the air, emissions to the water, and soil emissions [8].

\section{METHOD}

The first step of this research is data collection. The data that needed to collect are type of beam, kind of beam material, material collection sites, and the planning process of beam construction. The data was collected by interview with the parties: the Project Manager, the logistics department, and the manufacture/store.

Second step are data processing based on the Life Cycle Assessment using SimaPro 9.0 software. A detail sequences are:

a. Goal and Scope

In determining a goal, SimaPro 9.0 has two input methods, which are directly in the text field or in the libraries menu. While scope or limitation in SimaPro 9.0 is determined by the database namely Eco-invent database. Eco-invent database was chosen because it can determine the inputs and outputs. Inputs were material types and the distance of materials to the place of production. On the other hand, the output was the result of global warming emissions in $\mathrm{kg} \mathrm{CO}_{2}$ eq.

b. Inventory Analysis

Inventory Analysis is the most important part of LCA process. At this stage, all data that has the potential to cause emission include consumption energy in raw materials and transportation were collected.

c. Impact Assessment Analysis

The impact assessment method applied ReCiPe 2016 analysis. The use of the ReCiPe 2016 method is due to the commonly method and global analysis.

d. Interpretation

Interpretation is combination results of inventory analysis and impact assessment. This step functioned to evaluate result and to give solution based on the goals and scope that identified earlier.

\section{RESULTS AND DISCUSSION}

The object in this study is a house with type 216 in $13.5 \mathrm{~m} \mathrm{x} 16 \mathrm{~m}$. There are 4 types of beams: beam-type 25/50, beam-type 15/30, beam-type 15/15, and lintel beam-type 15/15. The goal of this study is to calculate $\mathrm{CO}_{2}$ emissions from each process and materials of beams. The scope of this research applied cradle to grave that starts from the raw material to the product operation process. Furthermore, Table 1 shows result of inventory analysis that consists of kinds of material and their quantities. Moreover, the distance of transportation is presented in Table 2. 
Table 1. Kind of Beam Material and The Quantities

\begin{tabular}{|c|c|c|c|c|}
\hline $\begin{array}{l}\text { Kind of } \\
\text { beam }\end{array}$ & $\begin{array}{c}\text { Volume } \\
\left(\mathrm{m}^{3}\right) \\
\end{array}$ & Kind of material & Quantities & Unit \\
\hline $\begin{array}{l}\text { Beam Type } \\
25 / 50\end{array}$ & 3,85 & $\begin{array}{l}\text { Multiplex } \\
\text { Wood Bar } \\
\text { Steel Wire Rod } \\
\text { Steel Rebar } \\
\text { Ready Mix Concrete } \\
\end{array}$ & $\begin{array}{r}198.562 \\
12,134.266 \\
13.297 \\
604.100 \\
8,970.500 \\
\end{array}$ & $\begin{array}{l}\mathrm{kg} \\
\mathrm{kg} \\
\mathrm{kg} \\
\mathrm{kg} \\
\mathrm{kg}\end{array}$ \\
\hline $\begin{array}{l}\text { Beam Type } \\
15 / 30\end{array}$ & 4,43 & $\begin{array}{l}\text { Multiplex } \\
\text { Wood Bar } \\
\text { Steel Wire Rod } \\
\text { Steel Rebar } \\
\text { Ready Mix Concrete }\end{array}$ & $\begin{array}{r}188.462 \\
10,886.021 \\
9.465 \\
538.460 \\
10,317.240 \\
\end{array}$ & $\begin{array}{l}\mathrm{kg} \\
\mathrm{kg} \\
\mathrm{kg} \\
\mathrm{kg} \\
\mathrm{kg}\end{array}$ \\
\hline $\begin{array}{l}\text { Beam Type } \\
15 / 15\end{array}$ & 0,11 & $\begin{array}{l}\text { Multiplex } \\
\text { Wood Bar } \\
\text { Steel Wire Rod } \\
\text { Steel Rebar } \\
\text { Ready Mix Concrete }\end{array}$ & $\begin{array}{r}52.645 \\
3,040.925 \\
2.644 \\
467.420 \\
264.746\end{array}$ & $\begin{array}{l}\mathrm{kg} \\
\mathrm{kg} \\
\mathrm{kg} \\
\mathrm{kg} \\
\mathrm{kg}\end{array}$ \\
\hline $\begin{array}{l}\text { Lintel Beam } \\
\text { Type } 15 / 15\end{array}$ & 0,3 & $\begin{array}{l}\text { Multiplex } \\
\text { Wood Bar } \\
\text { Steel Wire Rod } \\
\text { Steel Rebar } \\
\text { Cement } \\
\text { Sand } \\
\text { Gravel }\end{array}$ & $\begin{array}{r}17.376 \\
48.870 \\
0.873 \\
144.900 \\
125.280 \\
363.032 \\
423.538\end{array}$ & $\begin{array}{l}\mathrm{kg} \\
\mathrm{kg} \\
\mathrm{kg} \\
\mathrm{kg} \\
\mathrm{kg} \\
\mathrm{kg} \\
\mathrm{kg}\end{array}$ \\
\hline
\end{tabular}

Table 2. Material Retrieval Distance

\begin{tabular}{cccr}
\hline $\begin{array}{c}\text { Kinds of } \\
\text { material }\end{array}$ & Retrieval Location & Delivery Location & Distance $(\mathrm{km})$ \\
\hline Cement & $\begin{array}{c}\text { PT. Janti Sarana } \\
\text { Material Beton }\end{array}$ & Adong Property & 1.1 \\
Sand & CV. Adhie Karya Tama & Adong Property & 17.0 \\
Gravel & CV. Adhie Karya Tama & Adong Property & 17.0 \\
Steel Rebar & Toko Besi Sinarmas & Adong Property & 6.6 \\
Wood & UD. Wahyu Pratama & Adong Property & 8.8 \\
Ready Mix & PT.Surya Beton & Adong Property & 11.0 \\
Steel Wire Rod & Toko Karya Agung & Adong Property & 5.3 \\
\hline
\end{tabular}


The quality of concrete used in this project was K-250 which referred to SNI 7394 : 2008. The specific gravity of sand, gravel, and fresh concrete mix are $1800 \mathrm{~kg} / \mathrm{m}^{3}, 1400 \mathrm{~kg} / \mathrm{m}^{3}$, and $2330 \mathrm{~kg} / \mathrm{m}^{3}$, respectively. The rebars were stirrup reinforcement and main reinforcement. The reinforcement was plain steel bars with diameter $8 \mathrm{~mm}, 10 \mathrm{~mm}$ and $12 \mathrm{~mm}$, and threaded steel bars with diameter $13 \mathrm{~mm}$. For wood, it consists of three materials such as wood planks, wood bar, and multiplex with a size of $9 \mathrm{~mm}$ thick, $1.2 \mathrm{~m}$ long, and $2.4 \mathrm{~m}$ wide and weighs $16 \mathrm{~kg}$. The wooden beams that used in this project were meranti wood.

The third step is impact assessment analysis. The $\mathrm{CO}_{2}$ emissions as impact of beam life cycle are presented in network flow of each type of beam in Figure 1-4 as follows:

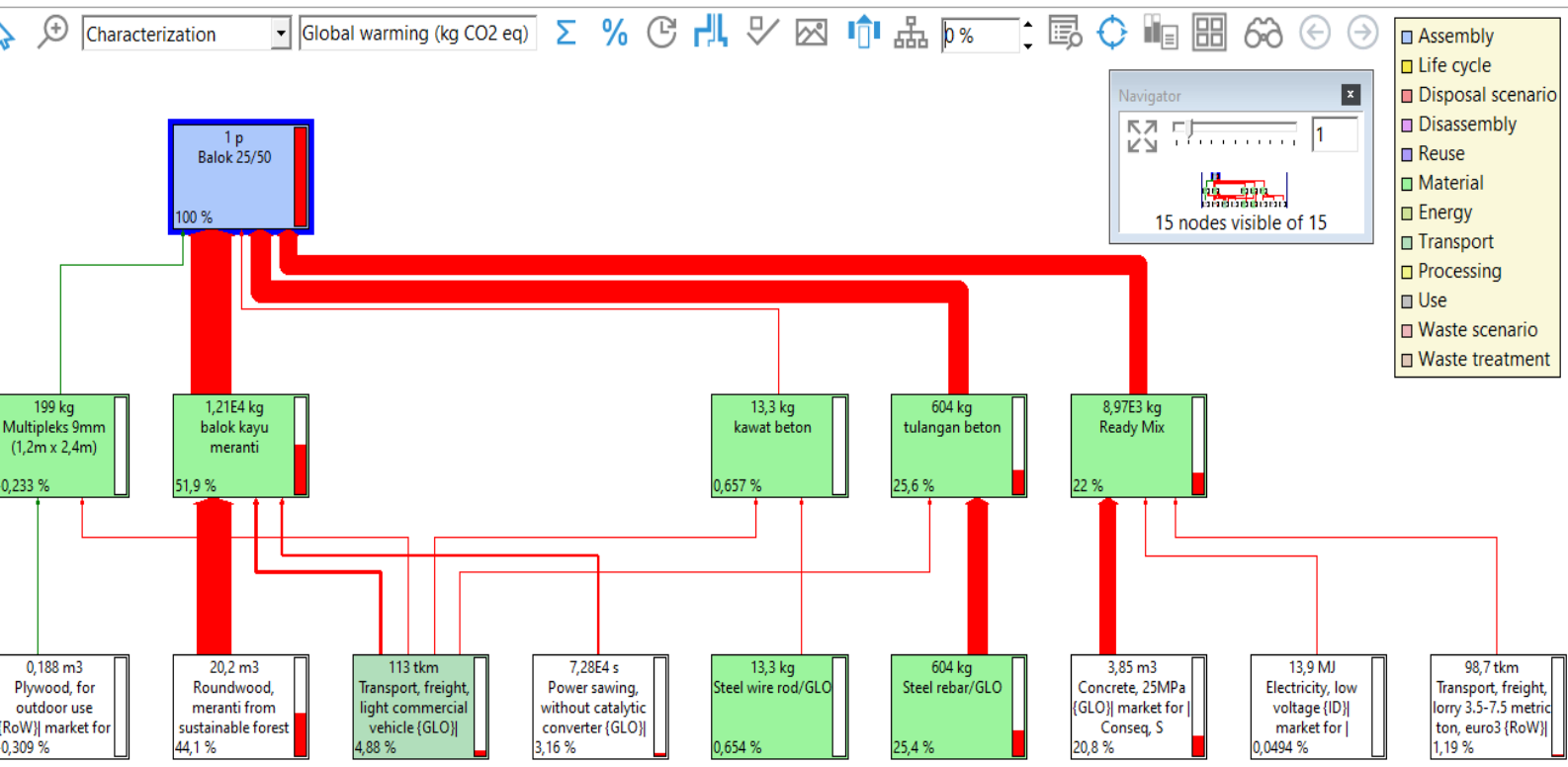

Figure 1. The $\mathrm{CO}_{2}$ Emission in Network Flow of Beam Type 25/50

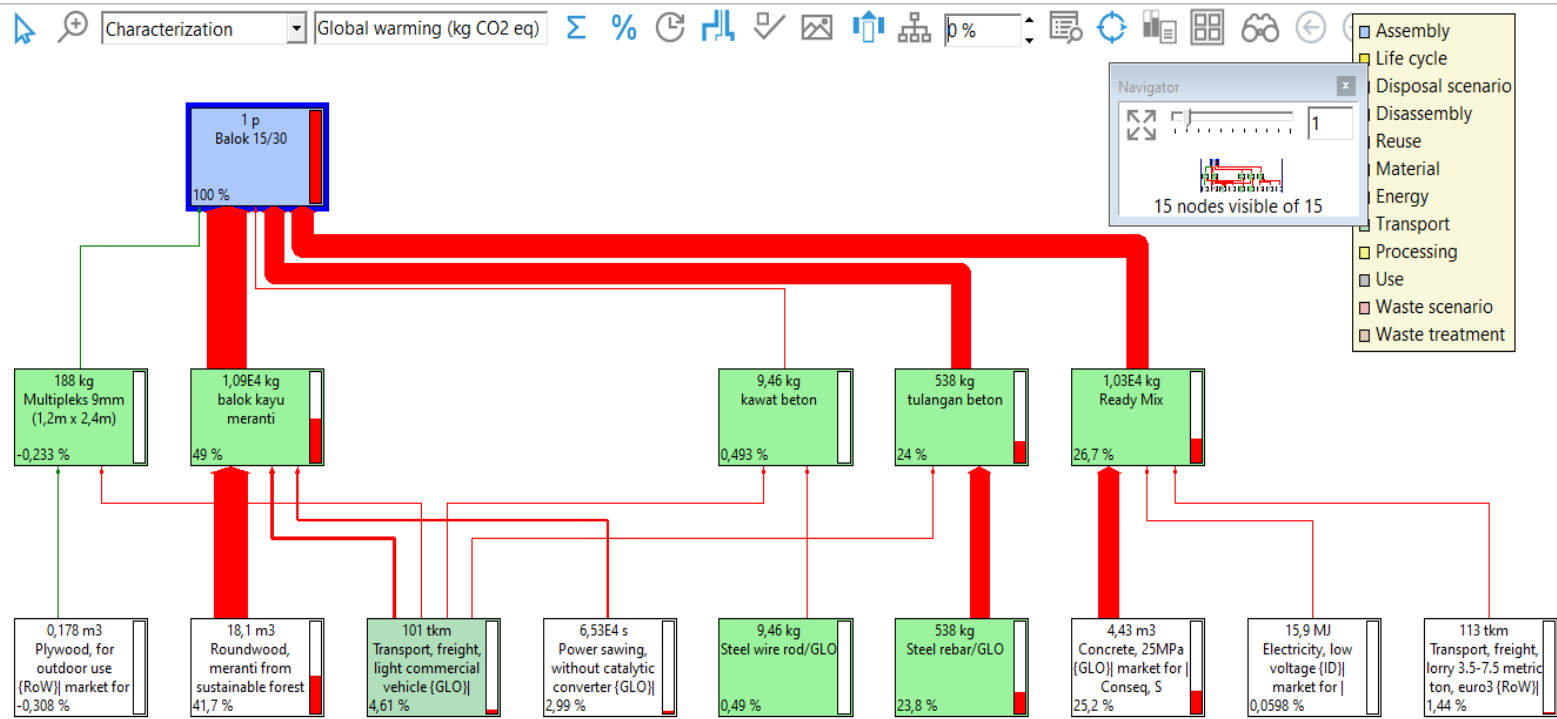

Figure 2. The $\mathrm{CO}_{2}$ Emission in Network Flow of Beam Type 15/30 


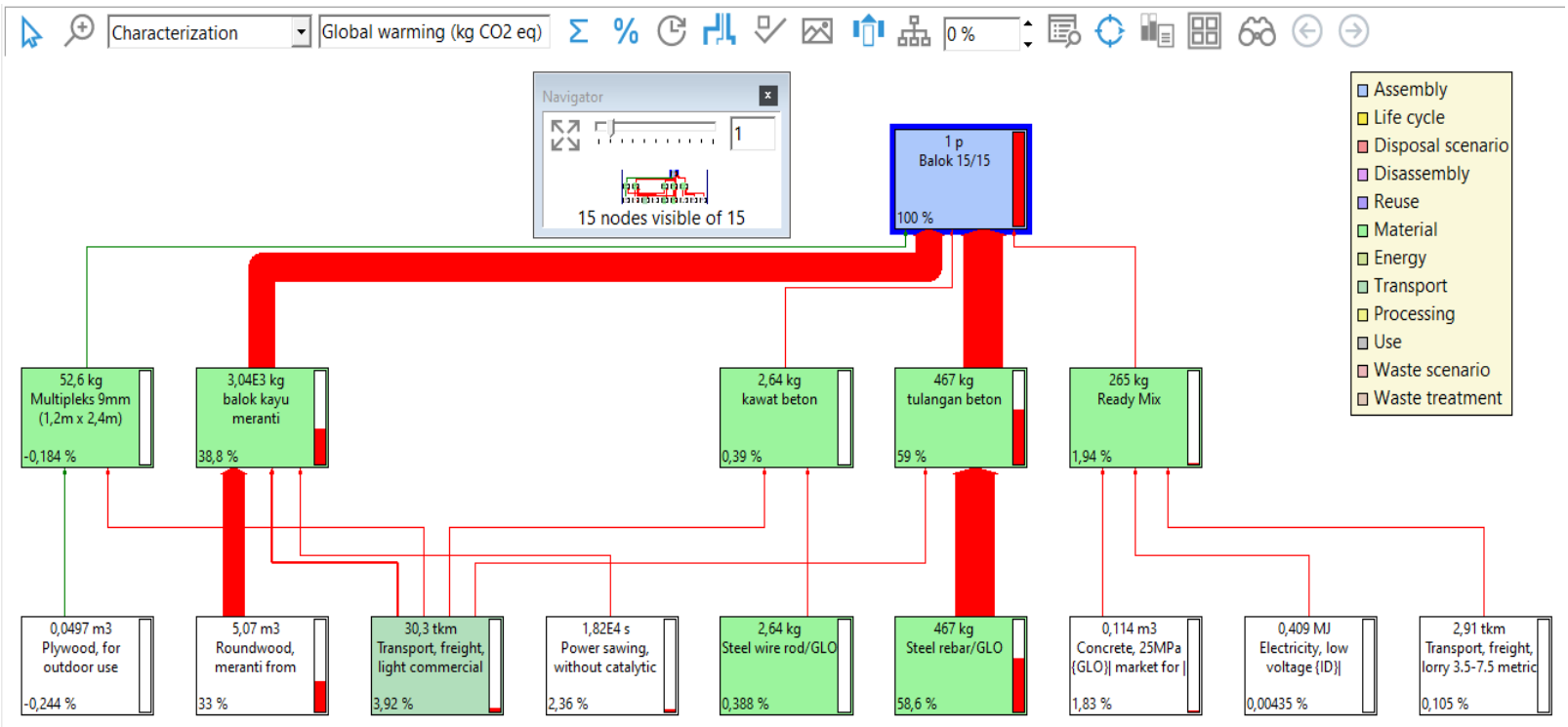

Figure 3. The $\mathrm{CO}_{2}$ Emission in Network Flow of Beam Type 15/15

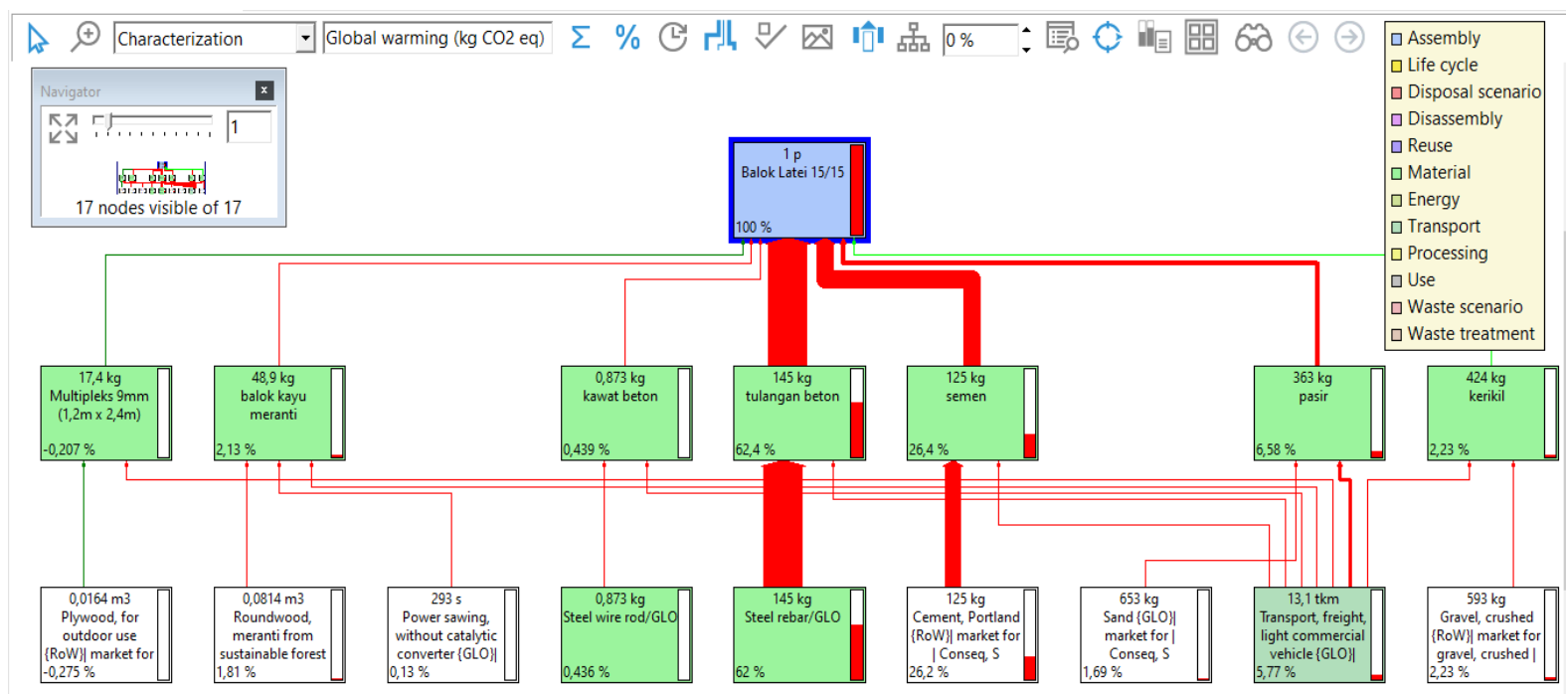

Figure 4. The $\mathrm{CO}_{2}$ Emission in Network Flow of Lintel Beam Type 15/15

The highest $\mathrm{CO}_{2}$-eq emission from beam is produced by beam type $25 / 50$ in $4,610 \mathrm{~kg}$ $\mathrm{CO}_{2}$-eq $(41.9 \%$ from total emissions of beam). The second highest $\mathrm{CO}_{2}$-eq emission followed by beam type $15 / 30$ and beam type $15 / 15$ with $4,380 \mathrm{~kg} \mathrm{CO}_{2}$-eq $(39.9 \%)$ and $1,550 \mathrm{~kg} \mathrm{CO}_{2}$-eq $(14.1 \%)$, respectively (see Figure 5). The volume of beam type $15 / 15$ are the lowest $(0.11$ $\left.\mathrm{m}^{3}\right)$ compare to beam type $25 / 50\left(3.85 \mathrm{~m}^{3}\right)$ and beam type $15 / 30\left(4.43 \mathrm{~m}^{3}\right)$. The lowest $\mathrm{CO}_{2}$-eq emissions is lintel beam-type $15 / 15$ in $454 \mathrm{~kg}$ $\mathrm{CO}_{2}$-eq $(4.13 \%)$. The construction methods of beam type $25 / 50$, type $15 / 30$ and type $15 / 15$ are ready mix methods. This is the reason why the emissions from these three types of beam generate high emission. On the contrary, lintei beam type $15 / 15$ was constructed by conventional method that produced lowest emission. It seem that quantities, volume/dimension, and construction methods affect the value of $\mathrm{CO}_{2}$-eq emission.

Based on the kind of materials of beam, for the conventional method, $\mathrm{CO}_{2}$-eq emission come from rebar of $3,426 \mathrm{~kg} \mathrm{CO}$-eq and cement $120 \mathrm{~kg} \mathrm{CO}$-eq. For the ready mix method, the largest $\mathrm{CO}_{2}$-eq emission are dominated by ready mix at $2,200 \mathrm{~kg} \mathrm{CO}_{2}$-eq and wooden blocks $5,150 \mathrm{~kg} \mathrm{CO}_{2}$-eq.

\section{CONCLUSIONS}

In beam construction, the highest $\mathrm{CO}_{2}$-eq emission from beam is produced by beam type $25 / 50$ in $4,610 \mathrm{~kg} \mathrm{CO}_{2}$-eq. For the conventional method, $\mathrm{CO}_{2}$-eq emission come from rebar of $31.20 \%$ and cement $1.09 \%$. For the ready mix method, the largest $\mathrm{CO}_{2}$-eq emission are dominated by ready mix at $20.20 \%$ and wooden blocks $46.90 \%$. 


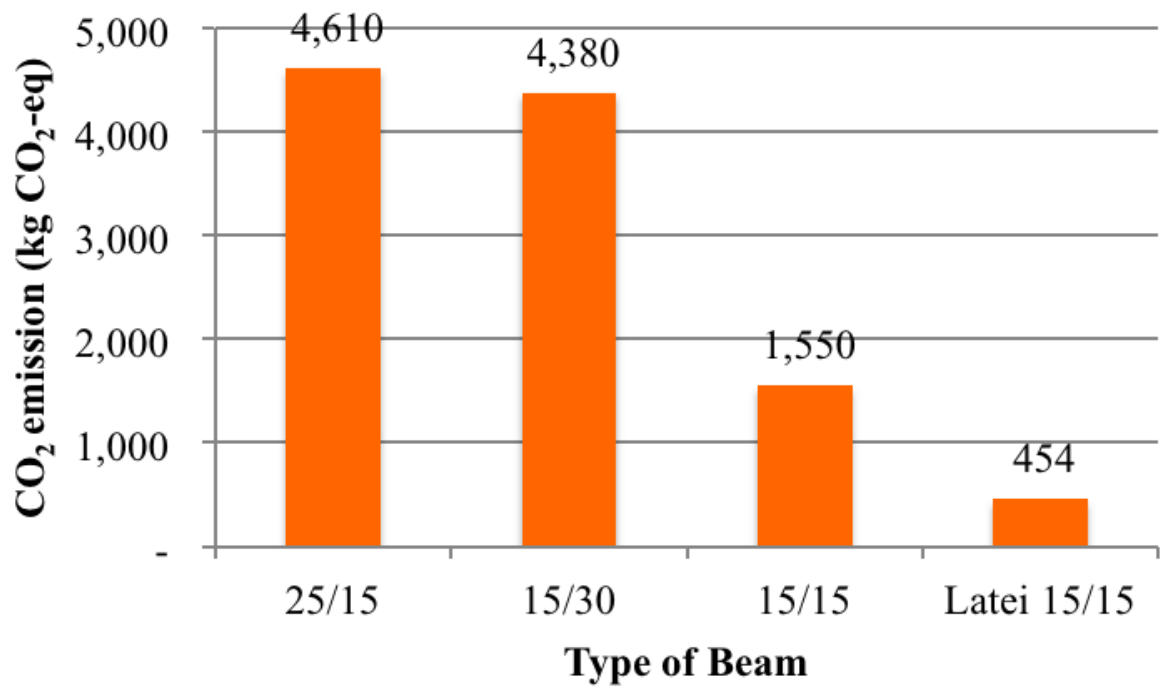

Figure 5. Total $\mathrm{CO}_{2}$ Emission for Each Type of Beam

\section{REFERENCES}

[1] Ervianto, W. I., Soemardi, B. W., Abduh, M., \& Suryamanto. (2013). Kajian Tentang Kerangka Legislatif Penerapa Green Construction dalam Proyek Konstruksi Bangunan Gedung di Indoesia. Seminar Nasional Teknik Sipil Ke IX, 1-17. Yogyakarta.

[2] Zabalza B.I., Valero C.A., \& Aranda U.A. (2011). Life cycle assessment of building materials: Comparative analysis of energy and environmental impacts and evaluation of the eco-efficiency improvement potential. Building and Environment, 46(5), 1133-1140. https://doi.org/10.1016/j.buildenv.2010.12.002

[3] ISO. (1997). Environmental management Life Cycle Assessment - Principles and Framework. International Organization for Standardization, 1997.

[4] Dipohusodo, I. 1994. Struktur Beton Bertulang.
Jakarta: Gramedia Pustaka Utama.

[5] ISO14067. (2018). Greenhouse gases Carbon footprint of products - Requirements and guidelines for quantification. International Organization for Standardization, 2018.

[6] IPCC.2006. General Guidance and Reporting. Journal of IPCC Guidelines for National Greenhouse Gas Inventories, 1(2006) chapter 1 page 1.5.

[7] Gabi. (2010). Handbook for Life Cycle Assessment ( LCA ) Using the GaBi Education. $1-66$.

[8] Hollerud B, Bowyer J, Howe J, Pepke E, Fernholz K. (2017). A review of life cycle assessment tools. Minneapolis: Dovetail Partners, Inc. 